\title{
Additional Notes
}

\section{Family Instructions for the Yan Clan 顔氏家訓}

I.

序致第 - reads 序致篇第一 in the Cheng Rong editions, and pian 篇 appears in all subsequent chapter titles. It reads 序致篇一 in the Fu Yue edition, and the subsequent chapter titles all follow the pattern.

\section{I.1}

耳 appears as the less common variant graph 尔 throughout the Bao Tingbo edition.

今所以復為此者: a note in the “Song edition" says that jin 今 is absent in a different edition.

\section{I.2}

凡人 reads 兄弟 in the Yan Sishen edition according to Wang Liqi (Wang 3).

\section{I.3}

誨誘 appears as 誘誨 in the 1789 print of the Lu Wenchao edition, but was corrected by Lu Wenchao in the errata in the 1792 reprint. Wang Liqi notes that except for the "Song edition" that he consulted, all editions read 誨誘 (4).

\section{I.4}

家塗 also reads 家徒 in the Cheng Rong edition.

不借邊幅 is emended to 不脩邊幅 in the Lu Wenchao edition.

\section{I.5}

三十 is a variant for 二十 given in a note in the "Song edition," which is adopted only in the Lu Wenchao edition. I follow the Lu Wenchao edition here.

\section{I.6}

經目過耳 also reads 經目過耳也 according to a note in the "Song edition," which is adopted by the Lu Wenchao edition. 
以為汝曹後車耳: a note in the “Song edition” says that 車 also reads 簯. This variant reading appears in the Fu Yue and Cheng Rong editions.

\section{II.2}

子生 reads 生子 only in the Lu Wenchao edition, which Wang Liqi follows.

咳㖷 also reads 孩提 according to a note in the “Song edition."

仁孝禮義 also reads 孝禮仁義 according to a note in the “Song edition.” Lu Wenchao emends it to 孝仁禮義, citing a Han shu passage, which Wang Liqi follows on the basis that "filial piety" is the foremost of all moral values (Wang 10). The Cheng Rong edition reads 仁智禮義. 當及嬰稚 reads 當撫嬰稚 in the Cheng Rong edition.

\section{II.3}

宜誡翻獎 also reads 宜訓翻獎 according to a note in the "Song edition." 應訶反笑 also reads 應訶反笑 according to a note in the "Song edition." 騎慢 also reads 憍慢 according to a note in the "Song edition." 方復 also reads 方乃 according to a note in the “Song edition." 無威 also reads 無改悔 according to a note in the "Song edition." 增怨 also reads 增怨澳 according to a note in the "Song edition."

\section{II.11}

若由此業 also reads 若用此業 according to a note in the “Song edition.”

\section{III.1}

有夫婦而後有父子 reads 有夫婦而後有父母 in the Bao Tingbo edition. I follow the Lu Wenchao edition here.

牟此三而已矣 reads 此三而已矣 in the Lu Wenchao edition (with a note of the "Song edition" variant) and others.

\section{III.2}

悖亂之行 reads 悖亂之人 in the Lu Wenchao edition (with a note of the "Song edition" variant) and others.

篤厚之行 reads 篤厚之人 in the Lu Wenchao edition (with a note of the "Song edition" variant) and others.

\section{III.3}

買於他人 reads 易於他人 according to a note in the "Song edition." 


\section{III.4}

皆有歡笑 reads 皆有歡愛 in the Lu Wenchao edition (with a note of the "Song edition" variant) and others.

\section{III.6}

何怨愛弟不及愛子乎 reads 何為愛弟不及愛子乎 in the Lu Wenchao edition.

良久方應 reads 良久方答 in the Lu Wenchao edition (with a note of the "Song edition" variant) and others.

\section{IV.1}

以賢父御孝子: 以 is missing in the Cheng Rong and Fu Yue editions.

\section{IV.2}

江左 reads 江右 in the Cheng Rong edition.

或不 reads 或未 in the Lu Wenchao edition and others.

\section{IV.7}

取其老者 reads 引其老者 in the Lu Wenchao edition and others.

\section{V.3}

如有周公之才之美 reads 雖有周公之才之美 in the Fu Yue and Cheng Rong editions.

施則奢 reads 奢則施 in the “Song edition." Lu Wenchao has a note saying all old editions read 奢則施 but emends it to 施則奢 in the context. The emendation is correct.

\section{V.7}

竟無括撻之意 also reads 竟無括撻 according to a note in the "Song edition," which is adopted in the Lu Wenchao edition and others.

V.9

誓满千人 reads 誓滿一千 in the Lu Wenchao edition and others. 朝夕看膳 reads 朝夕每人看膳 in the "Song edition" and is marked as a variant reading in a note, which is adopted in the Fu Yue and Cheng Rong editions. I follow the variant reading. 便無以兼 reads 更無以兼 in Cheng Rong edition and is marked as a variant reading in a note in the $\mathrm{Lu}$ Wenchao edition. 


\section{V.10}

常貧 reads 嘗貧 in the “Song edition” and is marked as a variant reading in a note. I follow the variant reading, which is also adopted in the $\mathrm{Lu}$ Wenchao edition.

\section{V.13}

河北人事 also reads 河北人士 according to a note in the "Song edition."

\section{V.15}

先人遗體 reads 先人傳體 in the Lu Wenchao edition and others.

\section{V.18}

部秩 reads 部怢 in the Cheng Rong edition, adopted by Wang Liqi with a long note (Wang 56). The emendation is not necessary. 犬鼠 also reads 蟲 $\xi$ according to a note in the “Song edition," and reads 大鼠 in the Cheng Rong edition.

\section{V.19}

勿妖安之費 is emended to 勿為妖安之費 in the Lu Wenchao edition, followed by Wang Liqi and Zhou Fagao.

\section{VI.1}

節文 reads 節度 in the Fu Yue and Cheng Rong editions. 仰記以傅示子孫 reads 聊記錄 in the Fu Yue and Cheng Rong edition.

\section{VI.2}

盖知 is emended to 益知 in the Lu Wenchao edition, followed by Wang Liqi and Zhou Fagao.

\section{VI.3}

又喊逢世, 藏嚴之子也 reads 又有藏逢世, 藏嚴之子 in the Lu Wenchao edition.

\section{VI.8}

凡名子者 reads 名子者 in the Fu Yue and Cheng Rong edition.

諱襄、諱周 reads 諱裹、諱友、諱同 in the Fu Yue and Cheng Rong editions, adopted in the Lu Wenchao edition. 


\section{VI.9}

亦鄙事也 reads 亦鄙才也 in Bao Tingbo's “Song edition” and is emended according to the other editions.

\section{VI.10}

況當之者乎 reads 況名之者乎 in the Fu Yue and Cheng Rong editions.

\section{VI.12}

陳思王稃其父日家父, 母曰家母: 日 reads 為 in the Fu Yue and Cheng Rong editions. Lu Wenchao adopts 為 with a note that the "Song edition” reads 日.

及南北風俗 is emended to 今南北風俗 by Wang Liqi following the “Song edition” he consulted (Wang 74).

蔡邑書集呼其姑姊為家姑家姊: 姑姊 reads 姑女 in all but the Wang Liqi and Zhou Fagao editions. Wang Liqi emends 姑女 to 姑姊 with a note saying he follows the Fu Yue (Fu Taiping) edition. Zhou Fagao also makes the same emendation but says that he follows a Qing reprint of the Yan Zhibang edition in Zheng Zhen's collection (Zhou 18a). Yan Shihui's 嚴式誨 (1890-1976) collation note says that the Fu Yue (Taiping) edition reads 姑姊 (Yan Shihui 679), but Zhou Fagao believes that in this case Fu Taiping is a mistake for Yan Zhibang.

\section{VI.15}

皆古之道也: 皆 is present in the "Song edition" but absent in the Fu Yue and Cheng Rong editions.

\section{VI.18a}

江南人事不獲已 reads 江南事不獲已 in the Fu Yue and Cheng Rong editions. A note in the "Song edition" states that after this line, a different edition has ten extra characters that read: 乃陳文墨, 㦎㦎無自言者. The extra line reads 乃堜文墨, 㦎㦎無言者 in the Fu Yue and Cheng Rong editions.

勿使煩重 also reads 勿取煩重 according to a note in the “Song edition," which is the reading in the Fu Yue and Cheng Rong editions.

\section{VI.19}

北上風俗 also reads simply 北土 according to a note in the "Song edition" and in the Fu Yue and Cheng Rong editions. 


\section{VI.20}

從父兄弟姊妹已孤 reads 從兄弟姊妹已孤 in the Lu Wenchao, Fu Yue, and Cheng Rong editions.

北土人多呼為姪 reads 北土人多呼為姪 in the Lu Wenchao, Fu Yue, and Cheng Rong editions.

並是對姑立稃 reads 並是對姑之稃 in the Lu Wenchao, Fu Yue, and Cheng Rong editions.

\section{VI.21}

甚以測凔 also reads 甚心測凔 according to a note in the "Song edition," which is the reading in the Fu Yue and Cheng Rong editions.

\section{VI.25}

乃有對面以相戲者 also reads 乃有對面以為戲者 according to a note in the "Song edition."

\section{VI.26}

字固因呼為字: the Lu Wenchao edition eliminates 因 with a note saying that it seems to be an error. Wang Liqi and Zhou Fagao both follow the Lu Wenchao edition.

\section{VI.30}

天套其算 reads 天套之算 in the Fu Yue and Cheng Rong editions.

亦不諭: a note in the "Song edition" says these three characters are absent in a different edition. It reads 亦不諭 in the Cheng Rong edition.

\section{VI.34}

北朝頓丘李構: 構 is replaced with a note "the imperial first name of the Retired Emperor" 太上御名 in the Bao Tingbao “Song edition" throughout the work. The Retired Emperor refers to Southern Song Emperor Gaozong 高宗 (r. 1127-1162) whose name was Zhao Gou 趙 構. He retired in 1162 and passed the throne to Emperor Xiaozong 孝宗 (r. 1163-1189). The "Song edition" was put into print during Emperor Xiaozong's reign.

同集談鮴 reads 同席談謾 in the Lu Wenchao edition. 


\section{VI.35}

江陵 reads 江夏 in the Lu Wenchao edition.

亦當不可綛食也 also reads 亦不可絕食也 or 亦常不可絕食 according to a note in the "Song edition."

\section{VI.37}

精神傷沮 reads 精神傷怛 in the Cheng Rong edition.

\section{VI.38}

來歲有社 also reads 來歲一社 or 來歲社 according to a note in the “Song edition." Zhao Ximing emends it to 來歲社日, followed by Wang Liqi and Zhao Fagao.

忌之外 reads 忌之日 in the “Song edition.” 忌之外 is the variant reading recorded in a note in the "Song edition." 日 is adopted by the Lu Wenchao edition, followed by Zhou Fagao; 外 is the reading in the Fu Yue and Cheng Rong editions and followed by Wang Liqi, who believes 忌之日 is wrong.

猶應感慕 reads 猶應思慕 according to a note in the “Song edition." It reads 尤應感慕 in the Lu Wenchao edition.

\section{VI.42}

梁孝元帝年少之時 also reads 梁孝元年少之時 according to a note in the "Song edition."

\section{VI.43}

于来反 reads 于來反 in the Fu Yue and Cheng Rong editions.

\section{VI.45}

怨䧾 reads 死䧾 in the "Song edition" with a note saying that it also reads 怨锥 in a different edition.

\section{VI.47}

親拜中兵參軍李鄭焉 also reads 親拜中兵參軍李猷 according to a note in the "Song edition."

\section{VI.48}

申父交之敬 also reads 申父友之敬 according to a note in the “Song edition." 


\section{VI.49}

黄門侍郎裴之禮, 好待實客, 或有此輩, 對传杖之, 僮僕引接, 折旋俯 仰, 莫不潚敬, 與主無別 also reads 黄門侍郎裴之禮, 號善為士大夫, 有 如此輩, 對賽杖之, 其門生僮僕, 接於他人, 折旋俯仰, 鲛色應對, 莫不 骕敬, 與主無別也 according to a note in the “Song edition.” The variant reading is adopted in all other editions.

\section{VII.1}

神醉魂迷 reads 心醉魂迷 in all other editions.

\section{VII.2}

言笑舉對 reads 言笑舉動 in all other editions.

\section{VII.3}

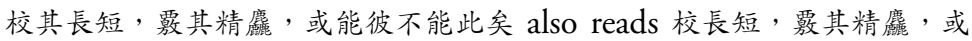
彼不能如此矣 according to a note in the “Song edition.”

\section{VII.5a}

一皆使典之 also reads 一皆使之 according to a note in the "Song edition.”

時云 is absent in another edition according to a note in the "Song edition."

王君一字 reads 王衰数字 in all other editions. It also reads 王君数字 according to a note in the "Song edition."

\section{VII.8}

關中至今譽之 reads 關中人至今譽之 in the Lu Wenchao edition.

\section{VII.9}

齊國之亡 also reads 齊亡之跡 according to a note in the "Song edition," which is adopted in all other editions.

\section{VIII.3a}

討諭貨賄 reads 計論貨賄 in the Cheng Rong edition.

沈思 also reads 深思 in the Cheng Rong edition.

射則不能穿札 reads 射既不能穿札 in the Fu Yue and Cheng Rong editions. 


\section{VIII.3b}

便自為足, 全忘修學 also reads 便謂為足, 安能自苦 according to a note in the "Song edition." The latter is the adopted reading in the Fu Yue and Cheng Rong editions.

\section{VIII.4b}

鹿獨戎馬之問 reads 孤獨我馬之問 in the Cheng Rong edition.

\section{VIII.5}

汝可不自勉耶 reads 安可不自勉耶 in all other editions.

\section{VIII.7}

文義習吏 reads 文義習史 in the Fu Yue and Cheng Rong editions.

\section{VIII.8b}

如秋茶 reads 幾秋茶 in the Cheng Rong edition.

\section{VIII.9b}

執繁如組 also reads 執繁生組 according to a note in the "Song edition." 早刑時唅 also reads 早刑晚捨 according to a note in the “Song edition." The latter is the reading adopted in the Fu Yue and Cheng Rong editions.

\section{VIII.10a}

以致甘膘 reads 以致甘㬓 in the “Song edition" with a note saying that it also reads 以致甘旨 in a different edition. It reads 膘 in all other editions.

\section{VIII.12}

今世人讀書者: jin is absent in a different edition according to a note in the "Song edition."

㯟避 reads 乘释 in the “Song edition.”

\section{VIII.14}

一月廢置 also reads 一日廢置 according to a note in the “Song edition." 便至荒葬矣 also reads 便荒黄矣 according to a note in the "Song edition." 


\section{VIII.15a}

始授孝經 is emended to 始受孝經 in the Lu Wenchao edition. It is unnecessary.

\section{VIII.16}

不肯專於經業 also reads 不肯專儒 according to a note in the “Song edition." The latter is the reading adopted in the Lu Wenchao, Fu Yue, and Cheng Rong editions, followed by Wang Liqi and Zhou Fagao.

\section{VIII.18}

爭此得勝 reads 以此得勝 in all other editions.

\section{VIII.20}

與諸博士爭宗廟事 reads 與諸博士議宗廟事 in all other editions.

\section{VIII.21b}

傾動專勢 reads 傾動權勢 in the Cheng Rong edition.

\section{VIII.21c}

清談雅諭, 䐱鋒理窟, 剖玄析微, 妙得入神, 實主往復, 娱心悦耳, 然而 濟世成俗, 終非急務 also reads 清談高諭, 剖玄析微, 賽主往復, 娱心悦 耳, 非濟世成俗之要也 according to a note in the “Song edition." The latter reading is adopted in all other editions.

\section{VIII.22}

故置學生 reads 召置學生 in all other editions.

\section{VIII.24}

閉齋 reads 閉齋 in the Fu Yue edition.

以自寬痛 also reads 以寬此痛 according to a note in the "Song edition."

\section{VIII.25}

亦云勤篤 also reads 亦為勤篤 according to a note in the “Song edition." 常無燈, 折荻尺寸, 然明讀書 also reads 燈燭難辦, 常買荻, 尺寸然明讀 書 according to a note in the “Song edition.” It reads 燈燭難辦, 常買 荻, 尺寸折之, 然明夜讀 in the Lu Wenchao, Fu Yue, and Cheng Rong editions, followed by Wang Liqi and Zhou Fagao. 


\section{VIII.26}

卒成大學 also reads 卒成學士 according to a note in the "Song edition."

\section{VIII.28}

齊有主宦者 also reads 齊有宦者 according to a note in the “Song edition."

後主之奔青州 also reads 齊主之奔青州 according to a note in the "Song edition.”

齊王 reads 齊主 in the Lu Wenchao edition, followed by Wang Liqi and Zhou Fagao.

以學著忠誠 also reads 以學成忠 according to a note in the "Song edition."

\section{VIII.29}

父當以教為事 also reads 父當以學為教 according to a note in the “Song edition." The latter reading is adopted in all other editions.

我自欲之 reads 吾自安之 in the Lu Wenchao edition.

\section{VIII.30}

謬謨着慗者多矣 also reads 謬誤差失, 慗者多矣 according to a note in the “Song edition.” The Lu Wenchao edition reads 謬誤差失者多矣.

\section{VIII.31}

孟勞者 is absent in a different edition according to a note in the "Song edition." This is the case in the Fu Yue and Cheng Rong editions.

\section{VIII.34}

遂謂朝士言 also reads 遂一一謂言 according to a note in the "Song edition." This is the reading in the Fu Yue and Cheng Rong editions.

\section{VIII.36}

必稃傸西 reads 必稃峽西 in the Lu Wenchao edition.

海郡 reads 海邦 in the Lu Wenchao edition.

\section{VIII.38}

笑吕忱 reads 忽吕忱 in all other editions.

專皮、鄒 is emended to 專徐、鄒 in the Wang Liqi edition (221-22). 


\section{VIII.39}

而有名歭者 reads 而有名峙者 in the Lu Wenchao and Cheng Rong editions, followed by Wang Liqi.

手邊 reads 手傍 in the Fu Yue edition (followed by Wang Liqi and Zhou Fagao) and 木傍 in the Lu Wenchao and Cheng Rong editions.

\section{VIII.42}

城南門 reads 城西門 in the Lu Wenchao, Fu Yue, and Cheng Rong editions, followed by Wang Liqi and Zhou Fagao.

\section{VIII.43}

忩遽者 reads 忽遽者 in the Cheng Rong edition and 忽遽者 in the Fu Yue edition, and 息遽者 in the Lu Wenchao edition, followed by Wang Liqi and Zhou Fagao. 忩 and 息 are variant forms of the same character.

\section{VIII.44}

初晴日晃 reads 初晴日明 in the Fu Yue and Cheng Rong editions.

命將取來 reads 命取將來 in all other editions.

\section{VIII.45}

舉俗 reads 舉族 in the Cheng Rong edition.

鴁 and 音分 are emended to 鸰 and 音介 in the Lu Wenchao edition, followed by Wang Liqi and Zhou Fagao.

\section{VIII.46}

梁世有蔡朗諱純 reads 梁世有蔡朗父諱純 in the Lu Wenchao edition; Wang Liqi reads 梁世有察朗者諱純. 蔡朗諱純 is correct and there is no need to emend it.

露葵菜 reads 露葵 in all other editions.

皦究 reads 覆究 in the Fu Yue and Cheng Rong editions.

\section{IX.1}

不可暫無 also reads 施用多途 according to a note in the “Song edition." The latter reading is adopted in all other editions.

\section{IX.2b}

訫忤楖里 reads 訫訶楖里 in the Fu Yue and Cheng Rong editions. 


\section{IX.4}

至無才思 reads 至於無才思 in the Fu Yue and Cheng Rong editions.

\section{IX.5}

得其評裁 reads 得其評諭者 in the Fu Yue and Cheng Rong editions. 知可施行: this is absent in the Fu Yue and Cheng Rong editions; the absence is marked as a variant reading in a different edition according to a note in the "Song edition."

便稃才士 reads 遂稃才士 in the Fu Yue and Cheng Rong editions.

要動俗盖世 reads 要須動俗盖世 in the Lu Wenchao, Fu Yue, and Cheng Rong editions.

\section{IX.6}

何事非君 reads 何事我為 in the Fu Yue edition.

\section{IX.7}

壯士 reads 壯夫 in the Lu Wenchao, Fu Yue, and Cheng Rong editions, followed by Wang Liqi and Zhou Fagao.

袁亮以勝老子 reads 桓譚以勝老子 in all other editions.

\section{IX.8}

席毗 reads 辛毗 in the Fu Yue and Cheng Rong editions.

譬若朝菌 reads 譬若㮡華 in all other editions.

千丈松樹 reads 十丈松樹 in the Fu Yue and Cheng Rong editions.

可哉 reads 可矣 in the Fu Yue and Cheng Rong editions.

\section{IX.9}

猶乘騏驞 reads 猶人乘騏䮓 in all other editions.

\section{IX.12}

撰西府新文紀無一篇見錄者 reads 撰西府新文史記無一篇見錄者 in the Cheng Rong edition and 撰西府新文史訖無一篇胃錄者 in the Fu Yue edition. The Wang Liqi edition reads 撰西府新文, 訖無一篇見錄者 by following and emending the variant reading in the $\mathrm{Fu}$ Yue edition.

\section{IX.14}

各為朋黨 reads 各有朋黨 in all other editions. 


\section{IX.17}

世人或有引詩 also reads 世人或有文章引詩 in all other editions.

\section{IX.19}

遂嘗以忤人 reads 遂嘗以此忤人 in all other editions.

\section{IX.21}

譬婦為考 reads 匹婦於考 in all other editions.

俔天之和 reads 俔天之妹 in the Yan Sishen edition (Wang Liqi 283).

\section{IX.22}

製作大意 reads 製作本意 in all other editions.

\section{IX.23}

踈失厥體 reads 殊失厥體 in the Fu Yue edition.

何不述郝王、露帝乎 reads 胡不述郝王、露帝乎 in the Lu Wenchao edition, followed by Wang Liqi. It reads 祠不述 in the Cheng Rong edition, which seems to be a typographical error.

\section{IX.24}

略舉一雨端以為誡云: 云 is absent in all other editions.

\section{IX.26}

痛心拔惱 reads 痛心拔腦 in the Lu Wenchao edition, followed by Wang Liqi and Zhou Fagao.

何故方言有如也 reads 何故言有如也 in all other editions except for Wang Liqi.

\section{IX.32}

常云: 常 is absent in the Fu Yue and Cheng Rong editions.

鿪車 reads 鿪居 in all editions, but in this case should be emended to 鿪車 as in the Wang Liqi edition (see Wang 298, 301). 居 and 車 are homophones, and a misunderstanding of Liu Xiaochuo's criticism (㦎 㦎不道車) may have led to the writing of 居 rather than 車. That is, many have taken 不道車 as meaning “not mentioning 'carriage." The correct interpretation is "unorthodox (or unrighteous) carriage." 


\section{IX.34}

亦為冠絕 reads 並為冠絕 in the Fu Yue and Cheng Rong editions.

\section{X.3}

拱把之梁 reads 拱抱之梁 in the Fu Yue and Cheng Rong editions. 仲由之言信 reads 仲由之證鼎 in the “Song edition," in which the former is given as a variant in a note.

\section{X.4}

虙 reads 宓 in the Fu Yue and Cheng Rong editions.

\section{X.5}

以孝著聲 reads 孝并著嶅 in the Fu Yue and Cheng Rong editions.

於苫塊之中 reads 以苫塊之中 in the Cheng Rong edition.

\section{X.6}

彪共吹嘘 reads 彪相吹嘘 in the Fu Yue and Cheng Rong editions.

亦常出境聘 reads 亦嘗出境聘 in all other editions.

面相討試 reads 面相討試爾 in the “Song edition."

\section{X.7}

大弊事也 reads 太幣事也 in the Cheng Rong edition.

\section{X.8}

功績遂損敗矣 reads 功績遂敗損矣 in the Fu Yue and Cheng Rong editions.

\section{X.9}

而聖人以為名教乎 reads 而聖人以為教乎 in the Fu Yue and Cheng Rong editions.

\section{X.10b}

獲其庇㗳者亦眾矣 reads 獲其庇侌者眾矣 in the Fu Yue and Cheng Rong editions.

世之汲汲者 reads 世人汲汲者 in the Fu Yue and Cheng Rong editions. 松柏偕茂者 reads 松柏偕茂 in the Fu Yue and Cheng Rong editions. 


\section{XI.1}

士君子之處世 reads 夫君子之處世 in the Fu Yue and Cheng Rong editions.

\section{XI.2}

開略有術 reads 開悟有術 in the “Song edition.”

\section{XI.3}

處廊廟之下 reads 處廟堂之下 in all other editions.

\section{XI.4}

所以處於清高 reads 所以處於清名 in the Fu Yue and Cheng Rong editions.

盖護其短也 reads 益護其短也 in the Cheng Rong edition.

\section{XI.6}

A note in the "Song edition" says that this section is absent in a different edition. This passage is missing in the Fu Yue and Cheng Rong editions.

\section{XI.7}

因晉中興, 南渡江, 卒為羈旅 reads 因至中興而渡江, 本為羈旅 in the Fu Yue edition.

At the end of this chapter, the "Song edition" has an additional section, with a note saying that this additional section appears at the end of Chapter XVI ("Keeping Faith") in a different edition. All other editions have this section at the end of Chapter XVI (as XVI.23 in this volume).

\section{XII.2}

不如熟一 reads 不如執一 in all other editions.

胡書 is absent in all other editions. The Wang Liqi edition follows the "Song edition."

\section{XII.3}

或無絲毫之益 reads 或無私毫之益 in the “Song edition.” 


\section{XII.4}

事途迴穴 is emended from 事途迴圥 in the Zhou Fagao and Wang Liqi edition. 圥 appears as the variant graph $几$ in the Fu Yue and Cheng Rong editions.

\section{XII.7}

便為“弗索何獲” reads 便謂 “弗索何獲” in the Lu Wenchao edition, followed by Wang Liqi and Zhou Fagao.

不然亦至也 reads 不求亦至也 in the Lu Wenchao edition, followed by Wang Liqi and Zhou Fagao.

\section{XII.8}

必以利治 is emended to 必以利殆 in the Wang Liqi edition. It is not necessary.

\section{XII.10}

亦不足恤焉 reads 又不足恤焉 in all other editions.

\section{XII.11a}

大抵諸儒所爭 reads 大抵諸儒所執 in the Lu Wenchao edition. 恥為此讓 reads 恥為此議 in the Fu Yue and Cheng Rong editions. 此好名之辱也 also reads 此好名好事之為也 according to a note in the "Song edition."

\section{XIII.1}

唯在少欲知足 reads 唯在少欲知止 in the Fu Yue and Cheng Rong editions.

\section{XIII.3}

皆以義散之 reads 以義散之 in all other editions.

\section{XIII.5}

夜填坑谷 reads 夜䫂坑谷 in the Lu Wenchao edition and (erroneously) 夜損坑谷 in the Cheng Rong edition.

慎之哉 is not repeated in the Lu Wenchao edition. 


\section{XIV.1a}

春秋之世 reads 春秋世 in the Lu Wenchao edition, followed by Wang Liqi.

顔高、顔鳴、顔息、顔羽之徒 reads 顔高、顔鳴、顔羽之徒 in the $\mathrm{Fu}$ Yue and Cheng Rong editions.

\section{XIV.1b}

趙有顔最 also reads 趙有顔聚 according to a note in the “Song edition."

\section{XIV.2}

趛弄拳拏: 笔 appears in its more common graphic form 腕 in the $\mathrm{Fu}$ Yue and Cheng Rong editions.

\section{XIV.3}

不能為主畫規 reads 不能為主盡規 in the Lu Wenchao edition, followed by Wang Liqi.

若居承平之世 reads 若承平之世 in the Fu Yue and Cheng Rong editions.

\section{XIV.4}

便騎乘 reads 便乘騎 in all other editions.

正可稃武夫爾 reads 上可稃武夫爾 in the Cheng Rong edition.

即自稃武夫兒 reads 即稃武夫兒 in all other editions.

\section{XV.1}

或難鍾值 reads 或難種植 in the Lu Wenchao and Cheng Rong editions. 幼少之日 reads 幼小之日 in the Lu Wenchao edition.

公私驅役 reads 公私勞役 in the Lu Wenchao edition.

千萬不遇一爾 reads 千萬不過一爾 in the Fu Yue and Cheng Rong editions.

學若牛毛 reads 學如牛毛 in all other editions.

暄寒 reads 寒暄 in all other editions.

\section{XV.2}

有單服杏仁、构杞、黄精、尤煎者 reads 有單服杏仁、柇杞、黄精、术、 車前 in all other editions. It reads 有單服杏仁、枸杞、黄精、尤煎、車 前者 in another edition according to a note in the "Song edition." 不能一一說爾 is absent in another edition according to a note in the "Song edition." 


\section{XV.3}

早朝建齒三百下為良 reads 早朝吒齒三百下為良 in all other editions. 建 齒 is the term used in The Master of Embracing Simplicity.

即便平愈 reads 即平愈 in the Fu Yue and Cheng Rong editions.

\section{XV.4}

諸欲飭藥 reads 凡欲飭藥 in all other editions.

不可輕脫 reads 不可輕服 in the Cheng Rong edition.

\section{XV.5}

夫養生者先須虑禍 reads 夫養生先須虑禍 in the Fu Yue and Cheng Rong editions.

石崇冀服飭之徵 also reads 石崇冀服慨之延年 according to a note in the "Song edition."

\section{XVI.1}

家世業此 reads 家世歸心 in all other editions.

其問妙旨 reads 其問妙音 in the Cheng Rong edition.

略重勸誘爾 reads 略動勸誘爾 in the “Song edition.”

\section{XVI.3}

漸極為異 reads 漸積為異 in the Wang Liqi edition only, which appears to be an error.

不淫之禁也 reads 不酒之禁也 in the Wang Liqi edition, with a note saying that he emended it based on the citation of this passage in the Guang Hongming ji (Wang, 368, 371).

固民之性 reads 因民之性 in the Fu Yue and Wang Liqi editions. Wang states that he emended 固 to 因 based on the "Song edition" and other editions that he has consulted (Wang 371). The emendation is not necessary.

\section{XVI.5}

莫著天地 reads 莫若天地 in all other editions.

\section{XVI.10}

原害、伯夷之谏餒 is emended to 伯夷、原害之谏餒 in the Wang Liqi edition based on Guang Hongming ji citation. It is unnecessary. 便生怨尤 reads 便可怨尤 in the Fu Yue and Cheng Rong editions. 則亦堯、舜之云虚 reads 則堯、舜之云虚 in the Lu Wenchao edition. 


\section{XVI.12}

失國賦算 reads 空國賦算 in all other editions.

\section{XVI.13}

頓欲臬之哉 reads 頓欲亶之乎 in the Guang Hongming ji citation (see Wang Liqi 396-97), in which it is followed by the sentence: 故雨疎得 其一隅，累代詠而彌光矣 (“The two Shu partially understood this issue, and even with their partial understanding they were eulogized and honored for generations"). The "two Shu" are the Western Han scholars Shu Guang 疏廣 and his nephew Shu Shou 疏受, who became tutors to the Crown Prince in $67 \mathrm{BCE}$. They retired after five years at the height of their fame, and were given a gift of twenty catties of gold by the emperor and fifty catties of gold by the Crown Prince. They spent all the gold entertaining their kinsfolk rather than pass it on to their children and were praised for their wisdom. The sentence in this context means that even if the two Shu only understood to a limited extent the importance of valuing one's own self, they were commended for generations.

\section{XVI.14}

汝曹若觀俗計 reads 汝曹若顧俗計 in the Fu Yue edition.

\section{XVI.16}

每沐䡛二三十枚 reads 每沐䡛二三十枚 in the Lu Wenchao edition, followed by Wang Liqi.

\section{XVI.17}

後生一兒頭俱是鮮 reads 後生一兒頭是鮮 in all other editions.

\section{XVI.19}

投醒而覺體痒 reads 稍醒而覺體痒 in all other editions. 投 has the meaning of "by the time when" and is correct here.

\section{XVI.23}

倚作舅姑之大 reads 倚作舅姑之尊 in all other editions.

惡口加誣 reads 毒口加誣 in all other editions.

卻成教婦不孝已身 reads 卻云教以婦道, 不孝已身 in the Fu Yue and Cheng Rong editions. 
但憐已之子女 reads 怛怜已之子女 in the Fu Yue and Cheng Rong editions.

不愛其婦 reads 不愛已之兒婦 in all other editions.

不得與為鄰 reads 慎不可與為鄰 in all other editions.

何況交結乎 reads 仍不可與為援 in the Fu Yue and Cheng Rong editions. 避之哉, 避之哉 reads 宜遠之哉 in the Fu Yue and Cheng Rong editions, and reads 避之哉 in the Lu Wenchao edition, followed by Wang Liqi.

\section{XVII.1}

接余也 reads 菨余也 in the Fu Yue and Cheng Rong editions.

\section{XVII.2}

禮云苦菜秀雨雅毛詩傳並以茶苦菜也 reads 雨雅毛傳並以茶苦菜也又禮云 苦菜秀 in the Fu Yue and Cheng Rong editions. Lu Wenchao emends the text accordingly, followed by Zhou Fagao and Wang Liqi.

\section{XVII.4}

案毛傳云 reads 案毛詩云 in the Fu Yue and Cheng Rong editions.

諸侯六䦥四種 reads 諸侯六䦥 in the Lu Wenchao edition.

\section{XVII.5}

月令云 reads 月令 in the Lu Wenchao edition.

但呼為早蒲 reads 但呼為早蒲 in the Fu Yue and Cheng Rong editions. 馬莧堪食 reads 堪食 in the Lu Wenchao, Fu Yue, and Cheng Rong editions.

俊晤 reads 俊悟 in the Fu Yue and Cheng Rong editions. 其伯父縚 reads 其伯父劉縚 in the Fu Yue and Cheng Rong editions.

\section{XVII.6}

恐為少誤 reads 恐有少誤 in the Lu Wenchao and Cheng Rong editions, followed by Zhou Fagao.

\section{XVII.8}

先需未有釋者 reads 先儒未有釋書 in the Cheng Rong edition.

五尺犬為猶 reads 六尺犬為猶 in the Lu Wenchao edition.

然後敢渡 reads 然後渡 in the Fu Yue and Cheng Rong editions. 


\section{XVII.9}

左傳日 is missing in the Lu Wenchao edition.

變而成痁 reads 變而成㗔 in all other editions.

\section{XVII.10}

景 in 准景響, 土圭測景, 景朝景夕, 圖景失形, 周雨問景 all read 影 in the Fu Yue and Cheng Rong editions, followed by Wang Liqi.

故即為景 reads 故即謂為景 in all other editions.

傍始加乡: a note in the “Song edition” gives the pronunciation for 乡: 音杉.

\section{XVII.11}

案諸陳隊 reads 案諸陳字 in the Fu Yue and Cheng Rong editions.

唯王羲之小學章 reads 唯王義小學章 in the Lu Wenchao edition.

\section{XVII.12}

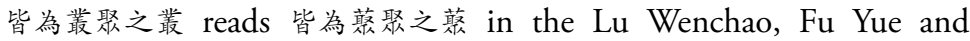
Cheng Rong editions.

又音祖會反 is missing in all other editions. Wang Liqi notes that this appears in an "original note" in the "Song edition" he consults. 又狙會反 reads 又祖會反 in all other editions.

\section{XVII.13}

曹大家注列女傳 reads 曹大家注烈女傳 in the Fu Yue and Cheng Rong editions. 列 is correct.

益誠可笑 reads 益成可笑 in the Lu Wenchao edition, followed by Wang Liqi and Zhou Fagao.

\section{XVII.14}

夏侯該: according to a note in the "Song edition," in another edition there is a note about 該, stating that He Ning's 和凝 (898-955) version cannot decide whether this character should be Yan 浐 or Yong 詠. 南方以晉家渡江後 reads 南方以晋渡江後 in the Fu Yue and Cheng Rong editions.

\section{XVII.17}

而復紫色越督 reads 復紫色䞪督 in the Fu Yue and Cheng Rong editions. 


\section{XVII.18}

則亦可以亥為豕字音 reads 亦可以亥為豕字音 in the Fu Yue and Cheng Rong editions.

\section{XVII.19}

是知虙之與伏 reads 是虑之與伏 in the Lu Wenchao edition.

\section{XVII.21}

聞其家堂客有擊筑 reads 聞其家堂上有客揧筑 in all other editions.

\section{XVII.23}

皆[]刻辭焉 does not have the empty space in the Fu Yue and Cheng Rong editions. The Lu Wenchao edition makes a note about the empty space.

刻此詔左 appears as 刻此詔 $\square$ 左 in the Lu Wenchao edition; $\square$ appears as an empty space in the Cheng Rong edition. The Fu Yue edition reads 刻此詔于左.

\section{XVII.24}

而江南書本, 多誤從手 reads 而江南書多誤, 從手 in the Lu Wenchao edition, with a note saying that since the text says 恐為誤 below, the 誤 in 多誤 here may be an error.

恐為談也 reads 恐為誤 in the Fu Yue and Cheng Rong editions.

\section{XVII.25}

猶割也 is absent in another edition according to a note in the "Song edition.”

\section{XVII.26}

為四姓小侯立學。按：reads 為四姓小侯立學校 in the Fu Yue and Cheng Rong editions.

\section{XVII.27}

鱣長二三丈 reads 鱣長二丈 in the Fu Yue and Cheng Rong editions. 


\section{XVII.28}

不入瞱城寺 is emended to 不入冀府寺 in the Lu Wenchao edition based on Fan Ye's biography in the History of the Later Han. However, chengsi 城寺 has the meaning of official headquarters and needs no emendation. 息當諭其六七耶 reads 禁當論其六七乎 in the Fu Yue and Cheng Rong editions.

\section{XVII.29}

此是削札牘之柿耳 reads 此是削札覑之杨耳 in the Fu Yue and Cheng Rong editions.

俗本因是悉作脯腊之脯 reads 俗本悉作脯腊之脯 in the Fu Yue and Cheng Rong editions.

或為反哺之哺字 reads 或為反哺之哺 in the Fu Yue and Cheng Rong editions.

\section{XVII.30}

北士通呼物一出 reads 北士通呼物一出 in the Cheng Rong edition.

目似擘椒 reads 目似[]椒 in the Cheng Rong edition, with an empty space for 㵨.

言監與蒜共一苞裹 reads 言監豉與蒜共苞一襄 in the Fu Yue and Cheng Rong editions.

\section{XVII.32}

常頽縱宏任 reads 常頽縱任俠 in all editions except Dong Zhenggong (Dong 17), which I follow. This sentence appears in Liu Xiaobiao's 劉 孝標 (462-521) commentary on the fifth-century anecdotal collection Shishuo xinyu 世說新語, which reads 曼䫋縱宏任, cited from “Yang Man's Unofficial Biography” 羊曼別傳 (Shishuo xinyu 6).

此字皆無音訓 reads 此字更無音訓 in the Fu Yue and Cheng Rong editions.

當是者老相傳 reads 當時者老相傳 in the Lu Wenchao edition.

蓋無所不見 reads 盖無所不施 in all other editions.

而二人皆云重邊 reads 而二人皆日重邊 in the Lu Wenchao edition.

\section{XV.34}

牡所以止扉也 reads 所以止扉 in all other editions.

督類作扊扅 reads 督類作扊 in all other editions. 


\section{XVII.35}

甚會近俗 reads 甚為近俗 in the Fu Yue and Cheng Rong editions.

\section{XVII.36b}

稀黝韓覆: several modern translators (Teng 177; Zhang Aitang 251) take "tattoo" here as a reference to Ying Bu, aka Qing Bu or the Tattooed $\mathrm{Bu}$ 點布, another general who also rebelled and was executed (see XVII.22). But there is a mention in Chen Xi's biography in the Historian's Record that his soldiers were tattooed as criminals after being defeated by the imperial army. The clause reads much more naturally with qing here as a verb than having a list of three names followed by one verb.

畔討滅残: according to a note in the "Song edition," another edition reads 畔討戚殊.

\section{XVII.37}

逐楖俗㶶謬 reads 遂楖俗叱謬 in the Cheng Rong edition.

木傍作鬼為鬼字 reads 木傍作鬼為槐字 in the Fu Yue and Cheng Rong editions.

\section{XVII.38}

即陸璣所謂聚藻葉如蓬者也 reads 即陸機所謂聚藻葉如蓬者也 in all other editions.

又郭类注三荅 reads 郭类注三荅 in the Fu Yue and Cheng Rong editions. 於時當紲六色罰 reads 於時當紲六色罰. I follow the Taiping yulan variant 紲 here, which makes better sense.

張敞因造系旁畏耳 reads 張敞因造絲旁畏耳 in the Cheng Rong edition.

\section{XVII.39}

土有巏㜈 reads 山有巏㜈 in the Lu Wenchao edition.

因云權務之精 reads 日權務之精 in the Fu Yue and Cheng Rong editions.

\section{XVII.40}

盈不至六 reads 盈不過六 in the Lu Wenchao edition.

\section{XVII.42}

當是前世有姓郭而病秃者 reads 當是前代人有姓郭而病秃者 in all other editions.

滑稽調戲 reads 滑稽戲調 in all other editions. 


\section{XVII.43}

其神降于長流之山: a note in the "Song edition" states that this is from the Shanhai jing, with 流 reading 留.

於祀主秋 reads 於祀為秋 in the Lu Wenchao edition.

\section{XVII.44a}

子皆謂非 reads 子皆為非 in the Lu Wenchao edition.

說文所明 reads 說文所言 in all other editions.

\section{XVII.44c}

導是禾名 reads 酥是禾名 in the Lu Wenchao edition. Lu Wenchao states that 導 is adopted in the Han History, followed by the sixthcentury Wen xuan; but 噵 is adopted in the Historian's Record.

\section{XVII.45}

互有同買 reads 各有同異 in the Fu Yue and Cheng Rong editions.

說文“尸”下施“几” reads 說文“居”下施“几” in the Bao Tingbo “Song edition," as well as the Fu Yue and Cheng Rong editions. I follow the emendation in the Lu Wenchao edition here.

\section{XVII.49}

宋書以召刀為劭 reads 宋書以召刀為邵 in the Lu Wenchao edition with a long note explaining the emendation.

拭卜 is emended to 栻卜 in the Wang Liqi edition.

\section{XVII.50}

古者暴㬉字與暴疾字相似 reads 古者暴覆字與暴疾字相似 in the Fu Yue and Cheng Rong editions.

\section{XVIII.1}

自春秋摽齊言之傳 reads 自春秋標齊言之傳 in the Lu Wenchao edition. 離騒目楚詞之經 reads 離騷目楚鲛之經 in the Lu Wenchao edition.

\section{XVIII.2}

加以內言外言 reads 加以外言内言 in the Fu Yue and Cheng Rong editions.

锋出 is glossed by Wang Liqi as "emerge like [a multitude of] blades" (539). But most likely it should be taken as the same as 蜂出 (variant 
form: 踽出), “emerge profusely and chaotically like a swarm of wasps," as in Shi ji 15.685: “矯稃䖯出, 誓盟不信.”

摧而量之 reads 權而量之 in the Cheng Rong edition.

\section{XVIII.6}

吾家子女 reads 吾家兒女 in all other editions.

\section{XVIII.8}

入室求日搜 reads 入室求日搜 in all editions and 入室求日[句] 搜 in the $\mathrm{Lu}$ Wenchao edition. I emend it according to the $X u$ Jiaxun edition cited in Wang Liqi (Wang 545).

\section{XVIII.10}

東郭牙望見桓公 reads 東郭牙望桓公 in all other editions.

\section{XVIII.13}

焉者鳥名 reads 焉字鳥名 in all other editions

或云語詞 reads 或云語墑 in the Lu Wenchao edition.

\section{XVIII.14}

而北人即呼為也字 reads 而北人即呼為也 in the Lu Wenchao edition. 此又為未定鲜乎 reads 此又為未定乎 in the Lu Wenchao edition. 下方列德以折之耳 reads 下乃列德以折之耳 in the Lu Wenchao edition. It reads 下方効德以折之耳 in the Cheng Rong edition.

\section{XVIII.16}

外無良師友故耳 reads 外無賢師友故耳 in the Cheng Rong edition.

\section{XVIII.17}

比世有人名暹 reads 北世有人名暹 in the Cheng Rong edition. 名㨞: a note in the "Song edition" gives the pronunciation: 音藥. 自稃為䲸: a note in the “Song edition” gives the pronunciation: 音㡜.

\section{XIX.2}

舉世准知其書 reads 舉世但知其書 in the Lu Wenchao edition. 


\section{XIX.3}

梁武祕閣散逸以來 reads 梁氏祕閣散逸以來 in all other editions.

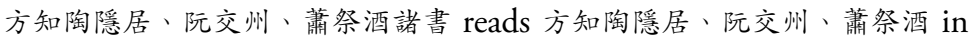
the Lu Wenchao edition.

莫不得羲之之一體 reads 莫不得羲之之逸體 in the Bao Tingbo “Song edition” and reads 莫不得羲之之體 in all other editions. Yan Shihui suggests that 莫不得羲之之逸體 should read 莫不得羲之之一體 based on a citation in Zhang Yanyuan's 張彦遠 (ca. 815-ca. 877) Fashu yaolu 法 書要錄 (Yan Shihui 693), which makes good sense.

\section{XIX.4}

郡陵王頗行偽字: according to a note in the “Song edition” here, another edition has a note here stating: "For example, writing cao ("grass") on top of qian ("front") or chang ("length; strength") besides neng ("ability”), and so on” (前上為草、能傍作長之類是也). This statement appears as part of the text proper in the Fu Yue and Cheng Rong editions, and demonstrates clearly that Yan Zhitui is speaking of graphic forms rather than calligraphic style here.

逐便轉移 reads 遂便轉移 in the Fu Yue and Cheng Rong editions.

\section{XIX.5}

姚元摽工於草隸 reads 姚元標工於楷隸 in the Fu Yue and Cheng Rong editions (followed by Wang Liqi), and reads 姚元標工於草隸 in the $\mathrm{Lu}$ Wenchao edition (followed by Zhou Fagao).

\section{XIX.6}

此乃陶隱居弟子杜道士所為 reads 乃陶隱居弟子杜道士所為 in the $\mathrm{Lu}$ Wenchao edition.

\section{XIX.7}

吾家嘗有梁元帝手畫蟬雀白團扇及馬圖 reads 吾嘗有梁元帝手畵蟬雀白橉 扇及馬圖 in the Lu Wenchao edition, and reads 吾家常有梁元帝手㶳蟬 雀白團扇及馬圖 in the Fu Yue and Cheng Rong editions. 晛古知今 reads 覞閲古今 in all other editions.

\section{XIX.9}

江南謂世之常射 reads 江南為世之常射 in the Fu Yue and Cheng Rong editions. 


\section{XIX.10}

今人生疑於卜 reads 今人疑生於卜 in the Lu Wenchao edition.

\section{XIX.12}

玉軨變、玉歷十許種書 reads 玉熟、玉歷十許種書 in the Fu Yue and Cheng Rong editions. In the "Song edition" there is a note saying that a different edition reads 玉栐、玉歷十許種書. It is possible, as Wang Liqi surmises, that Yuling 玉軨 is an error for Yuqian 玉軨 (Jade Lock), a phrase that appears in several Daoist titles (see Yan Zhitui's "Poem on Immortals" in this volume).

\section{XIX.13}

至如反支不行 reads 如反支不行 in the Lu Wenchao edition.

\section{XX.2}

已啟求揚都 reads 啟求揚都 in the Fu Yue and Cheng Rong editions.

XX.4

隨為私記耳 reads 隨為私記 in the Fu Yue and Cheng Rong editions.

\section{XX.5}

及七月半孟蘭盆, 望於汝也 reads 及畫忠信, 不辱其親, 所望於汝也 in the Fu Yue and Cheng Rong editions. The variant deletes the mention of the Buddhist festival and makes the statement strictly "Confucian."

\section{“Poem on Immortals” 神仙詩}

Lu Qinli 2283; Wenyuan yinghua 225; Gu shi ji 110; Wang Liqi 718; Zhang Aitang 425-26.

\section{“Ancient Theme: Two Poems”古意詩二首}

I

Lu Qinli 2283; Yiwen leiju 26; Gu shi ji 110; 1.7 cited in Taiping yulan 196; Wang Li 709; Zhang Aitang 431-32.

7 数從明月讌 reads 屡陪明月宴 in Taiping yulan. 
8 During his first tenure as governor of Jingzhou (526-539), Xiao Yi had an affair with a local girl named Li Tao'er 李桃兒. He took her with him when called back to the capital in 539, but it was a violation of regulations, and his brother and successor, Xiao Xu 萧續 (504-547), threatened to inform the emperor of his misconduct. Xiao Yi was forced to send $\mathrm{Li}$ Tao'er back to Jingzhou, and wrote a poem in which he referred to her as the goddess of Wu Mountain (Lu Qinli 2060). The love story was well-known to contemporaries and celebrated in poems, in which Xiao Yi's Sunny Cloud Tower, with its allusion to the goddess of Wu Mountain, is associated with Li Tao'er (Tian 2018: 146).

23 不獲殉陵墓 reads 未獲殉陵墓 in $G u$ shi ji.

II

Lu Qinli 2283; Yiwen leiju 26; Gu shi ji 110; Wang Liqi 712; Zhang Aitang 432-33.

10 價值詎連城 reads 價直距連城 in Yiwen leiju.

\section{“A Companion Piece to Adviser Yang's 'Listening to the Singing Cicadas”和陽納言聽鳴蟬篇}

Lu Qinli 2284; Chuxue ji 30; Gu shi ji 110; Wang Liqi 714-15; Zhang Aitang 428-29.

According to Bei shi 30, after the Northern Qi was conquered by the Northern Zhou in 577, several Qi courtiers who were brought to Chang'an, the Zhou capital, wrote poems on this topic together. Besides Yan Zhitui's piece, the one by Lu Sidao (see note to IX.33) is also extant. The acclaimed poet Yu Xin was said to have read all the poems and particularly admired Lu Sidao's piece.

2 Chuxue ji reads 秋蝉悲非一處.

31-34 Gu shi ji has a note saying that the lines beginning with 紅顔宿 昔同春花 contain some lacunae. These four lines are set apart from the preceding lines in Wang Liqi. 秋華 reads 秋草 in $G u$ shi ji, followed by Lu Qinli, Wang Liqi, and Zhang Aitang; but 秋華 is correct because 華 (MC hwae) rhymes with 花 (MC xwae) and 車 (MC tsyhae). 


\section{“Passing by Dizhu at Night on the Way from Zhou to Qi"} 從周入齊夜度砥柱

Lu Qinli 2283-84 and 2190 (under Daoist Master Huimu, see note below); Wenjing mifu lun "East"; Wenyuan yinghua 289; Yinchuang zalu 1, 14; Gu shi ji 110; Wang Liqi 720-21; Zhang Aitang 427.

Gu shi ji has a note saying, "The Beautiful Couplets of Liang Lyricists (Liang ciren liju 梁詞人麗句) attributes it to a Daoist master Huimu 惠 慕道士 instead, and the title reads 'I Encountered the Northern Enemies and Was About to Flee, and Composed This Poem' ("Fanlu jiang tao zuo" 犯虜將逃作).” The editorship of the Beautiful Couplets of Liang Lyricists is attributed to the Tang poet Li Shangyin 李商鿵 (ca. 813ca. 858); the work consists of poems by fifteen sixth-century authors, including the Western Liang (or Later Liang) Emperor Ming 梁明帝 (Xiao Kui 萧潞, r. 562-585) as well as ghosts' poems and children's rhymes. It is preserved through the twelfth-century work, Yinchuang zalu (14).

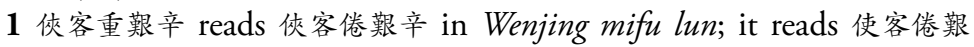
辛 in Shige (Yinchuang zalu 1) and 客子倦莫辛 in Liang ciren liju (Yinchuang zalu 14, and Lu Qinli 2190).

4 雞鳴起戍人 reads 雞鳴越戍人 in Shige (Yinchuang zalu 1).

5 露鮮華澰彩 reads 露鮮花斂影 in Shige (Yinchuang zalu 1) and $\mathrm{Lu}$ Qinli 2190; it reads 露鮮花劒影 in Wenjing mufu lun as well as Liang ciren liju (Yinchuang zalu 14).

8 北海就孫富 reads 北海問孫富 in Shige (Yinchuang zalu 1).

\section{“Rhapsody on Viewing My Life” 觀我生賦}

Bei Qi shu 45; Lu Wenchao Zhuan 2b-16a; Yan Kejun, Quan Sui wen 13.4088-90; Wang Liqi 657-703; Dien 42-71; Zhang Aitang 307-39. 25 問我辰之安在 is emended from 問我良之安在 in $\mathrm{Lu}$ Wenchao, followed by Wang Liqi and Zhang Aitang. I adopt the emendation here. 27 Original Note: Shouming 授命 means to offer one's life and service to one's lord or one's state. Rather than "giving him [Hou Jing] life," shou qi ming here refers to "offering his [Hou Jing's] service." The phrase is used in the same sense as in a forged letter of submission to 
the Wu ruler, written by the Wu courtier Hu Zong 胡綜 (183-243) in the name of the Wei courtier Wu Zhi 吴質 (177-230): “Now, with sincerity, I, your subject, offer my service from afar” 今臣款款, 遠授其 命.

55-56 Original Note: 湘洲刺史河東王譽 reads 相洲刺史河東王臖 in several editions of Bei Qi shu (see collation notes). Xiang 湘, which is adopted in the text proper, is correct.

60 扶車 (“assisting the carriage") is unclear. Lu Wenchao suggests it is an error for 綠車, also known as 皇孫車 (Imperial Grandson's Carriage), a type of carriage for the imperial grandson to ride in. Qian Daxin 錢 大昕 (1728-1804), on the other hand, proposes that it is a corruption of Fusu 扶䚢 (d. 210 BCE), the eldest son of the First Qin Emperor who failed to become his successor (see Wang Liqi 665). Lu Wenchao's suggestion makes more sense, since this couplet is about the imperial grandson, not about the son, Xiao Tong. Fusu died of suicide under order of a forged imperial decree after the passing of the First Emperor; the circumstances do not fit Xiao Tong's death.

60 Original Note: 嫡皇孫 reads 嬌皇孫 in Yan Kejun.

67 子既䫂 reads 子既損 (“A son was lost”) in Yan Kejun and Wang Liqi. Either variant does not change the meaning of this phrase.

69-70 Original Note: 府 in 河東府褚顯族據投岳陽 reads 苻 in one of the Bei Qi shu editions. Dien believes that Yueyang here refers to the city of Yueyang in Xiangzhou, not the Prince of Yueyang (Dien 135). However, there is no evidence supporting this claim.

79-80 Original Note: 汪 reads 注 in the base editions of Bei Qi shu and is emended to 汪.

85-86 Original Note: “Suining du” 綏䕗度 is unclear. Qian Daxin believes $d u$ 度 should be hou 侯 (marquis).

104 向詡 reads 白詡 in all older editions of Bei Qi shu, Lu Wenchao, and Yan Kejun. It is emended in Wang Liqi (see Wang 670-71), Dien (50), and Zhang Aitang (315). I adopt the emendation.

108 地道 reads 他道 in Bei Qi shu, Lu Wenchao, and Yan Kejun. It is emended in Wang Liqi (see Wang 670-71), Dien (50), and Zhang Aitang (315). I adopt the emendation.

113 先主 reads 先生 in $B e i Q i$ shu and is emended to 先主 in $\mathrm{Lu}$ Wenchao.

115-16 Original Note: Shen Jiong 沈畑 (502-560) uses the term “taking off clothing" in speaking of his own impending execution (and his 
last-minute escape) at the hand of Hou Jing's general Song Zixian in his "Rhapsody on the Returned Soul” (“Guihun fu” 歸魂賦), and the account of his experience in Qiu Yue's 丘悦 (fl. 708) Summary Documents of the Three Kingdoms (Sanguo dianlue 三國典略) uses the term “taking off clothing to go to execution” 解衣就翏.

122 衣露: I take 衣露 as 依露, “relied-on fog," which makes more sense in the context than "[those who are] clothed in fog." Dragons and snakes were thought to rely on cloud and fog to ascend to the sky (see Lu Wenchao 7b). It also forms a better parallel with 假履 (literally, "borrowed shoes") in the next line.

123-24 Original Note: 十一月十九日 (January 1, 552) reads 十二月十 九日 (January 30, 552) in Lu Wenchao, Yan Kejun, and Wang Liqi. 盖 天道紀大数 reads 䒹天道紀大数 in Bei Qi shu and 茟天道繼大数 in all other editions; I emend 芛 to 盖 based on the collation note in Bei Qi shu. The original note is missing in Zhang Aitang. Dien states that Zizhi tongjian 資治通鑑 gives the yichou 乙丑 day of the eleventh month (December 22, 551). However, Zizhi tongjian gives the jichou 已丑 day of the eleventh month, which was exactly the nineteenth day (Zizhi tongjian 164).

133 Chou 㺼 is used here in the sense of "who," as in: "Who dares not to respectfully follow the excellent command of my king” 德敢不祗若 王之休命 (from the Book of Documents), or "Who could defy and lose reason, and yet preserve his life” 疇逆失而能存 (from Sima Xiangru, "On Feng and Shan Ceremony").

155-56 Original Note: 侯景既走, 義師採鮨失火 reads 侯景既平, 我師 採稩失火 in Lu Wenchao, Yan Kejun, Wang Liqi, and Zhang Aitang. 穞 reads 櫓 in various editions of Bei Qi shu and is emended to 穞.

163 Original Note: 吏部尚書宗懷正、員外郎顔之推: Dien believes the text is corrupt and this line should be emended to 吏部尚書宗懔、正員 郎颜之推 (Dien 152). Zong Lin 宗懔 (500-563) was a native of Jiangling and was made Minister of Personnel by Emperor Yuan. 王孝紀 reads 王孝純 in Lu Wenchao, Yan Kejun, and Wang Liqi. 宗善業 reads 宗菩業 in Lu Wenchao, Yan Kejun, and Dien, and reads 宗菩善 in Wang Liqi and Zhang Aitang.

175-76 Original Note: Lu Wenchao, Wang Liqi, and Zhang Aitang all take Prime Minister Yuwen 宇文丞相 as Yuwen Jue 宇文覺 (542-557), the son of Yuwen Tai. 
177-78 民百萬而因處, 書千雨而煙湯 reads 人民百萬而因處, 書史千雨 而煙湯 in Lidai minghua ji 1 .

180 斯文盡拨 reads 斯民盡韍 in Yan Kejun.

180 Original Note: 墳籍 reads 墳典 in one Bei Qi shu edition.

186 幹人神之無狀: Lu Wenchao believes 無狀 is an error, perhaps because the phrase is already used in 1.182 (孙老疾之無狀). He proposes emending to 無杖 (“not to be relied on").

195-96 小臣恥其獨死, 實有愧於胡顔: 恥其獨死 is literally “ashamed about dying alone." It is taken by Dien to mean his being ashamed by Emperor Yuan's lonely death (Dien 59); but one would not refer to his ruler's death in such bald terms. Huyan 胡顔 is literally "what face [does one have for not hastening to die].” The couplet here can be compared with 1l. 23-24 in “Ancient Theme” I: 不獲殉陵墓, 獨生良足恥.

198 Original Note: 官給疲驢瘦馬 reads 官疲龭瘦馬 in Bei Qi shu and Yan Kejun.

203 五牛 reads 玄牛 in Bei Qi shu and Yan Kejun.

210 仙弓 reads 仙宫 in Bei Qi shu and Yan Kejun.

242 陽侯 reads 陽度 in Bei Qi shu and is emended to 侯 in Lu Wenchao. 267 誎 reads 誎 in Bei Qi shu and Yan Kejun.

269-70 Original Note: 之推爾日隣禍, 而儕流或有毁之推於祖僕射者 reads 之推爾日隣祜而免, 佸流或有毁之推於祖兴射者 in Lu Wenchao (13b), Wang Liqi (698), and Zhang Aitang (335).

271 予 reads 子 in one of the Bei Qi shu editions and Yan Kejun.

276 惰琢玉之遗祉: Lu Wenchao believes 惰 should be 墮, “to ruin.” 277-78 Original Note: this note is missing in Zhang Aitang. 279 度政: Lu Wenchao suspects that it should be 庶政.

304 郊郷導: Bei Qi shu collation note suspects that 郊 should read 效. 309 信諂謀於公王 reads 信諂謀於公主 in a number of editions of $\mathrm{Bei}$ Qi shu, Lu Wenchao, Yan Kejun, and Wang Liqi. I follow the emendation, though imperfect, in Bei Qi shu (see collation note).

309-310 Original Note: in the name 高阿那胘, 䏠 should be pronounced gong but was pronounced as gui 瓖 by contemporaries (Bei $Q i$ shu 50). Dao 道 here is pronounced as, and interchangeable with, dao 導, "to lead or show the way," as in "Our humble domain will show you the way” 敝邑為道 (The Zuo Tradition, Duke Yin 5), or “I shall go before and show you the way" 來吾道夫先路 (from “Li sao" in the Lyrics of Chu). To translate dao as "on the road" as Dien did (69) does not make grammatical sense in the context. 
314 屯: I take zhun here as a verb, "reach the fullness of," not as the name of the hexagram.

313-14 Original Note: 趙郡李穆叔調妙占天文算術：commentators believe that 調 here is superfluous.

317 鳥焚林 reads 鳥焚株 in Yan Kejun.

328 入溙 reads 入秦 in $\mathrm{B} e i$ Qi shu, Lu Wenchao, and Yan Kejun.

334 亮身: Lu Wenchao takes it to mean “nourish one's person," and so do Dien's and Zhang Aitang's translations. However, in early and early medieval writings, when shen is used with gao, it is always for the body to become a source of nourishment, i.e., to die and sacrifice one's body. For instance, 身亮草野 (Han History); 爭亮身於夷狄以要功名 (History of the Later Han). I translate the phrase accordingly.

\section{“Rhapsody on Questioning the Sages”稽聖賦 [Fragments]}

Wang Liqi, “Yan Zhitui ji jiyi” 顏之推集輯伙 (Wang 722-23), except for \#8 and \#14. Zhang Aitang, 442-44. Note: Zhang Aitang follows Wang Liqi, but mistakenly removes \#11 to a list of "Erroneous Attributions to Yan Zhitui" (Zhang 449).

Note: The rhapsody had two commentaries, one by Yan Shigu and the other by Li Chunfeng 李淳風 (602-670).

1.

Cited in Cui Guitu's 崔狍圖 (ca. $9^{\text {th }}$ century?) commentary on the Record of the Northern Gateway (Beihu lu 北户錄) 1. The "Northern Gateway" was the name of a mythical kingdom in the farthest south, and this work is an account of the customs and products of Lingnan (in modern Guangxi and Guangdong) by Duan Gonglu 段公路 (fl. 869-871). Xin Tang shu claims that Duan was the grandson of the prime minister Duan Wenchang 段文昌 (773-835).

2.

Cited in Augmented $\mathrm{Ya}$ (Pi Ya 埤雅) 2, "Explaining Fishes," a work by Lu Dian 陸佃 (1042-1102). The citation attributes the rhapsody to Yan Zhou 顔籍 (Yan Shigu's given name), mixing the commentator with the author of the rhapsody. 


\section{3.}

Cited in $\mathrm{Pi} \mathrm{Ya} 7$, introduced simply with "Yan Zhitui says." Wang Liqi decides that it is from his "Rhapsody on Questioning the Sages."

\section{4.}

Cited in $\mathrm{Pi} \mathrm{Ya} \mathrm{7,} \mathrm{introduced} \mathrm{with} \mathrm{"Yan} \mathrm{Zhitui} \mathrm{says."}$

5.

Cited in Pi Ya 7.

6.

Cited in $P i Y a 10$.

7.

Cited in Pi Ya 11.

8.

Cited in Pi Ya 11.

Note: this fragment is not included in Wang Liqi's "Yan Zhitui ji jiyi” 顔之推集輯佚.

9.

Cited in Pi Ya 15.

10.

Cited in Pi Ya 16.

11.

Cited in the Account of Species Responding to One Another (Wulei xianggan zhi 物類相感志) 16, an encyclopedic work in eighteen scrolls attributed to Su Shi 葪軾 (1037-1101). However, according to Song bibliographies, there was a Wulei xianggan zhi in ten scrolls authored by the Buddhist monk Zanning 贊䋰 (919-1001). In Wulei xianggan zhi, this fragment is cited in the entry on "Cicadas" 蟬. The citation is followed by a quotation from the commentary on the rhapsody: 
注：抱朴子曰：“有自然之蟬, 有荇菜䔄、芩根、土龍之屬皆化蟬。”

According to its commentary, Baopuzi says, 'There are naturally formed cicadas; there are also cicadas transformed from the stems of water-fringe, the root of runner-reed, or earthworms and their like."

The Baopuzi citation is followed by a comment presumably made by the compiler of Wulei xianggan zhi, which is (erroneously) taken by Wang Liqi as part of the Baopuzi citation (Wang 723):

今驗水澤巨樹處多水䖵登岸, 穴有烈化出為蛞也。

Nowadays we can testify to this by observing that where are big trees near a body of water, there are often water bugs climbing onto the shore, some of which may turn into cicadas.

I take rong 几 here as rong 容, “perhaps” (cf. Wang Liqi’s transcription of the last line: 空有裂化出為蟬也). The Baopuzi citation above appears in Taiping yulan 937.4298, with minor differences (田地既有自然之鰏 而有荇莢芩根土龍之屬化為鱓), and this has been included in Appendix I of Baopuzi neipian. However, one should note that Taiping yulan includes the Baopuzi citation under the entry on "Eel” (shanyu 鱓魚), not on "Cicada" (chan 蟬). There is another item from Taiping yulan (1000.4556) citing Baopuzi: "The root of the qin plant turns into eel" 墓根化為鮥. Qin is identified as an aquatic plant and probably an alternative graph for qin $\mathrm{H}$.

12.

Cited in The Carried Bodkin (Pei xi 佩觡) by Guo Zhongshu 郭忠恕 (d. 977).

\section{3.}

Wang Liqi gives the following passage, cited in Beihu lu 1 as being from Yan Zhitui's rhapsody:

水母, 東海謂之䖳 (音蜡), 正白濛濛如沫。

"Water-mother" is called jellyfish [pronounced as $z h a$ ] on the east coast. It is pure white, varied and numerous, like foam. 
Wang Liqi believes that this passage, unrhymed, is not part of the rhapsody itself but rather of Yan Shigu's commentary. He is likely correct, although we cannot be certain whether it is from the commentary by Yan Shigu or by Li Chunfeng. It is reasonable to assume that the commentary is about shuimu ("water-mother") mentioned in Yan Zhitui's rhapsody.

The full citation from Beihu $l u$ reads as follows and should be given in its entirety in Wang Liqi for the reason I will explain below:

稽聖賦云: 水母, 東海謂之䖳 (音蜡), 正白濛蒙如沫, 生物, 皆別無 眼耳, 故不知避人, 常有蝦依隋之, 蝦見人驚, 此物亦隨之而驚, 以 蝦為目自衛也。

According to "The Rhapsody on Questioning the Sages," watermother is called jellyfish [pronounced as zha] on the east coast; it is pure white, varied and numerous, like foam. It is a living creature, but has no eyes or ears, so it does not know to avoid people. A shrimp is always attached to it. When it sees people, the shrimp is startled, and the creature to which the shrimp is attached also becomes startled. Thus it uses the shrimp as its eyes for self-defense.

This is in turn cited from the Account of the Southern Yue (Nan Yue zhi 南越志) by Shen Huaiyuan 沈懷遠 (fl. 454-465), which is preserved, with only minor differences, in Li Shan's 李善 (d. 689) commentary on Guo Pu’s 郭璞 (276-324) "Rhapsody on the Yangzi River" “Jiang fu” 江賦) in Wen xuan 12.563:

海岸間頗有水母, 東海謂之䖳, 正白, 濛蒙如沫, 生物, 有智識, 無 耳目, 故不知避人。常有蝦依隨之, 蝦見人則驚, 此物亦隨之而沒。

By the seashores there are a great many "water-mothers." It is called jellyfish on the east coast. It is pure white, varied and numerous, like foam. It is a living creature with sentience, but has no eyes or ears, so it does not know to avoid people. But a shrimp is always attached to it. When it sees people, the shrimp is startled, and this creature to which the shrimp is attached also vanishes with the shrimp.

Thus the commentary on Yan Zhitui's rhapsody must have come from Nanyue zhi and should be quoted in its entirety. 


\section{4.}

Cited in Du Guangting 杜光庭 (850-933), A Record of the Immortals Gathering at Yongcheng (Yongcheng jixian lu 墉城集仙錄) 6; also in Taiping guangji 479.3945 (cited from Yuanhua zhuan shiyi 原化傳拾遗, with Yuanhua zhuan perhaps being a variant version of Yuanhua ji 原 化記, a late ninth century story collection).

Note: this fragment does not appear in Wang Liqi's "Yan Zhitui ji jiyi" 顔之推集輯伕.

爱有女人 reads 安有女 in Taiping guangji.

Note: Wang Liqi gives a fragment that he finds in the Sound and Meaning of All Scriptures (Yiqie jing yinyi 一切經音義) by the Buddhist monk Huilin 慧琳 (737-820) and believes it to be from Yan Zhitui's rhapsody: "The crow dwells in fire, but does not burn; the hare resides in water, but does not drown”鳥處火而不燋, 兔居水而不溺 (Yiqie jing yinyi 51). Upon close examination, there is no clear indication that this is the case. Rather, it seems to be Huilin's summary of a passage from Wang Chong's Lun heng. Huilin does cite Li Chunfeng's commentary on Yan Zhitui's rhapsody, but it seems to merely consist of a citation from $\mathrm{Ge}$ Hong's Baopuzi. There is no clear evidence that Li Chunfeng was refuting Yan Zhitui in his commentary as Wang Liqi speculates here (Wang 724). 
